\title{
Articulatory Accuracy and Variability by Word Familiarity and Phoneme Difficulty in Children with and without Speech Sound Disorders
}

\author{
Ji-Su Janga, Seunghee $\mathrm{Ha}^{\mathrm{b}}$ \\ ${ }^{a}$ Graduate Program in Speech Language Pathology, Hallym University, Chuncheon, Korea \\ ${ }^{b}$ Division of Speech Pathology and Audiology, Audiology and Speech Pathology Research Institute, Hallym University, Chuncheon, Korea
}

Correspondence: Seunghee $\mathrm{Ha}, \mathrm{PhD}$ Division of Speech Pathology and Audiology, Audiology and Speech Pathology Research Institute, Hallym University, 1 Hallymdaehak-gil, Chuncheon 24252, Korea

Tel: +82-33-248-2215

Fax: +82-33-256-3420

E-mail: shha@hallym.ac.kr

Received: April 5, 2021

Revised: April 30, 2021

Accepted: May 21, 2021
Objectives: This study aims to examine the articulatory accuracy and variability according to word familiarity and phoneme difficulty in children with speech sound disorders (SSD) and typically developing children. Methods: The participants were 10 children with SSD and 14 typically developing children aged from 2 years 6 months to 2 years 11 months. The 20 target words were selected according to word familiarity and phoneme difficulty. Each child was asked to produce each target word three times and the percentage of correct phonemes and variability scores were obtained. Results: The results showed that articulatory accuracy of children with SSD was significantly lower and their articulatory variability was significantly higher than those of typically developing children. There was no significant difference in articulatory accuracy according to word familiarity, but there was a significant difference in articulatory variability. Significant differences were found in articulatory accuracy as well as variability according to phoneme difficulty. Conclusion: This study suggested that phoneme difficulty affects articulatory variability in children with and without SSD aged 2:6-2:11. The articulatory variability and the related significant factors were discussed from the perspective of normal and delayed/abnormal speech acquisition processes. The study has useful implications for diagnosis and intervention for young children with SSD below 3 years old.

Keywords: Speech sound disorder (SSD), Word familiarity, Phoneme difficulty, Accuracy, Variability 말소리장애(speech sound disorder, SSD)란 지속적인 발음 및 말 소리 산출 문제를 겪으며 의사소통에 어려움이 있는 경우를 말한 다(Kim \& Shin, 2015). 말소리장애의 원인을 파악하고 적절한 평가 와 중재를 제공하기 위하여 말소리장애를 발생 시기, 심각도, 병인 론(원인) 등의 기준으로 분류하려는 연구들이 이어져 왔다. 그 중 에서 Dodd (2005)는 말소리장애 하위유형을 표면 음운 오류 패턴 을 바탕으로 조음장애, 음운지연, 일관적인 음운장애, 비일관적인 음운장애로 분류하였다. 이 중 비일관적인 음운장애는 25 개의 동 일한 그림을 제시하여 세 번씩 이름대기를 실시하였을 때 검사어의 $40 \%$ 이상을 서로 다른 형태로 산출하는 변이적 특성을 가진 집단 이다. 즉, 동일한 단어를 반복적으로 산출할 때 서로 다른 형태의
산출이 나타난다. 이는 음운 체계의 미성숙을 의미하며 다른 말소 리장애 유형과 구분된다.

변이성은 아동이 말소리를 습득해가는 정상적인 말 발달 과정에 서 나타나, 성인의 발음 형태를 찾아가는 재조직 과정의 하나로 해 석되기도 한다(Han \& Ha, 2017; Holmm, Crosbie, \& Dodd, 2007; Sosa \& Stoel-Gammon, 2006). 아동은 점차 성장해 나가며 조음 정 확도가 증가하고, 변이성은 감소하는 발달적 경향을 보인다(Burt, Holm, \& Dodd, 1999; Holm et al., 2007; Hwang \& Ha, 2012; Kim \& $\mathrm{Ha}, 2016 ; \mathrm{McLeod} \&$ Hewett, 2008). 따라서 연령이 증가함에도 불 구하고 비일관적인 발음 형태가 높은 비율로 관찰되는 아동의 경 우 아동기 말실행증(Childhood Apraxia of Speech, CAS) 혹은 비 
일관적 음운장애로 진단될 수 있다. 이에 Holm 등(2007)은 발달 과정 속에서 일반 아동에게 관찰될 수 있는 정상적인 변이성과 말 소리장애 아동이 보일 수 있는 특성으로서 비일관성을 구분하고 그 특징을 파악해야한다고 언급하였다.

연구자들은 말소리장애 아동의 비일관성을 구분하기 위해 일반 아동의 발달 과정에서 나타나는 변이성을 먼저 이해하고자 하였다. Schwartz, Leonard, Folger와 Wilcox (1980)가 1세 7-9개월을 대상 으로 연구를 진행한 결과, 아동들은 두 개의 단어 중 하나를 3 가지 의 형태로 산출하였다. McLeod와 Hewett (2008)이 2-3세 일반 아 동을 대상으로 진행한 연구에서는 목표단어의 $53.7 \%$ 가 변이적으 로 산출되었다. Holm 등(2007)에서는 3세 0 개월부터 3세 5개월의 일반 아동이 목표단어의 $13 \%$ 를 변이적으로 산출하였으며, $86 \%$ 는 3 회 중 적어도 한 번은 단어를 정확하게 산출하였다. 동일한 연구에 서 6 세의 경우 목표단어의 $2.6 \%$ 를 변이적으로 산출하였고, $98.2 \%$ 는 3 회 중 적어도 한 번의 정확한 산출을 하여 연령이 증가함에 따 라 변이성이 감소하고 조음 정확도가 증가하는 경향이 나타났다.

국내 연구를 살펴보면 Hwang과 $\mathrm{Ha}$ (2012)는 2세 6개월부터 4세 11 개월까지의 일반 아동에게 2-4음절의 단어를 4 회씩 산출하도록 하여 변이성을 측정하였다. 아동의 연령이 높아질수록 일관적인 산출을 보였다. 2 세 후반과 3 세 사이에 급격하게 변이성이 감소하 기 시작하였고 4 세가 되면 변이성이 나타나지 않아 비교적 안정적 인 산출을 보였다. Kim과 Ha (2016)는 24-36개월 일반 아동을 대 상으로 자발화 속에서 단어 변이성과 음소 변이성을 살펴보았다. 선행연구에서는 단어 변이성은 아동이 2회 이상 말한 어휘 중 그 형태가 서로 다르게 산출된 어휘의 비율을 의미하였다. 음소 변이 성은 아동의 자음 목록에 있는 음소 중에 서로 다른 형태로 발음된 음소의 비율에 해당하였다. 단어 변이성은 2 세 전반에서 $52 \%, 2$ 세 후반 $36 \%$ 로 감소하는 경향이 나타났으며 음소 변이성은 2 세 전반 에서 $69 \%, 2$ 세 후반에서 $52.45 \%$ 로 나타나 단어 변이성과 함께 감 소하는 경향을 보였다.

선행연구들에서 변이성이 두드러지는 연령이 조금씩 다르게 나 타났지만, 대다수의 연구결과(Hwang \& $\mathrm{Ha}, 2012 ; \mathrm{Kim} \& \mathrm{Ha}$, 2016; McLeod \& Hewett, 2008)는 2세 일반 아동을 중심으로 변이 성이 두드러지는 것으로 나타났다. 초기 음운 습득 단계인 2 세는 표 현어휘가 빠른 속도로 증가하고 낱말 조합이 이루어지는 시기이다. 이 시기에는 음운체계의 미성숙으로 인하여 변이성이 나타나고 발 달 속도에 따라 개인차도 두드러진다. 동적 시스템 이론(Dynamic systems theory)에 따르면 발달 과정에서 나타나는 변이성은 발달 단계 간의 전이와 관련된다(Thelen \& Bates, 2003). 발달 전환 과정 의 아동은 새로운 패턴을 탐구하고 음운의 재구조화를 하는 과정
에서 조음 변이성을 보인다. 따라서 변이성은 발달의 잠재적 원동력 이자 지표로 여겨진다. 이러한 발달적 지표가 두드러지는 2 세는 발 달적 관점에서 중요한 시기로서 그 특징을 자세히 살펴볼 필요가 있다. 그러나 국내의 2세 변이성 연구들(Hwang \& Ha, 2012; Kim \& $\mathrm{Ha}, 2016)$ 은 그 대상이 일반 아동으로 국한되어 말소리장애 아동 의 특징까지 살펴보기는 어려웠다. 말소리장애 아동과 일반 아동 을 비교한 연구(Han \& Ha, 2017)는 3-6세를 대상으로 하였기 때문 에 일반적으로 변이적인 말 특성을 가장 두드러지게 보이는 2 세 아 동의 특징은 알 수 없었다. 따라서 본 연구에서는 말 발달 과정 상 일반적으로 변이성이 두드러지는 2 세 일반 아동과 비교해 말소리 장애 아동의 변이성이 어떠한 특징을 보이는지 살펴보고자 한다.

변이성에 영향을 줄 수 있는 요인으로 여러 가지가 논의되어 왔 다. Macrae (2013)는 변이성의 잠재적인 원인으로 아동의 미숙한 구어 운동능력, 언어적 시스템의 불안정성, 단어의 음운 및 구조적 특징, 산출과 습득의 단위가 전체 단어에서 음소로의 전환, 음운론 적 복잡성, 어휘 지식 등을 제시하였다. Macrae (2013)는 이 중에서 도 어휘적 요인과 음운적 요인을 고려하여 아동들의 변이성을 살 펴보고자 하였다. 습득연령과 음운론적 복잡성을 고려하여 20개 의 목표단어를 제작하였으며 이에 따른 정확도와 변이성을 확인하 였다. 그 결과 어휘 친숙도에 따라서 정확도와 변이성은 유의미한 차이가 없었으며, 음운론적 복잡도에 따라서는 정확도와 변이성 모두 유의미한차이가 나타났다.

Sosa와 Stoel-Gammon (2012)은 변이성에 영향을 미칠 수 있는 어휘적 요인 중 하나로 목표단어의 습득 연령을 제시하면서, 이는 단어의 친숙성과 연관된다고 제안하였다. 즉, 아동이 빨리 습득하 는 단어는 친숙한 단어, 비교적 늦게 습득하는 단어는 비친숙한 단 어로 가정하였다. Sosa와 Stoel-Gammon연구에서는 친숙한 단어 가 비친숙한 단어보다 안정적인 산출을 보일 것이라 기대하였으나, 비친숙한 단어가 친숙한 단어보다 더 정확하게 산출되었다. 연구자 들은 이러한 결과를 늦게 습득한 비친숙한 단어는 최근의 음운 시 스템으로 수정이 되었지만, 이전에 습득한 친숙한 단어는 아직 최 근의 음운 시스템으로 수정되지 않았기 때문이라고 해석하였다. 반면 1 세 9 개월부터 3 세 1 개월까지의 15 명 아동을 대상으로 한 Macrae (2013)에서는 앞서 언급한대로 단어 친숙도는 조음 정확도 와 변이성에 유의미한 영향을 미치지 않아 예측변수로 작용하지 않았다. 한편 Kim과 $\mathrm{Ha}$ (2016)는 일반 아동이 변이성을 보인 어절 을 살펴본 결과 한국판 맥아더-베이츠 의사소통발달평가(Korean version MacArthur-Bates Communicative Development Inventories, K M-B CDI; Pae \& Kwak, 2011)의 수용 및 표현어휘 목록에 포 함되지 않은 비친숙한 단어가 높은 비율로 포함되어 있었다. 이에 
단어 친숙도와 변이성 간의 부적 관련성을 제시하였다. 말소리장애 아동의 조음 능력에 관한 연구에서 수용 및 표현어휘 능력과 같은 어휘 지식은 빈번하게 고려되어 왔으나 단어 친숙도를 고려한 경우 는 찾아보기 어려웠다. 따라서 추가적인 연구로 단어 선정에 친숙 도를 반영할 필요가 있다.

변이성에 영향을 줄 수 있는 음운적 요인 중 하나로는 단어에 포 함된 음소의 난이도가 있다. Macrae (2013)는 더 복잡한 소리에서 낮은 정확도와 높은 변이성이 발견되어 단어 친숙도 외에 변이성에 영향을 주는 또 다른 요인이 음소 난이도로 나타났다. 이러한 결과 는 Sosa와 Stoel-Gammon (2012)에서 3세 미만의 아동들을 대상으 로 하였을 때에도 동일하게 나타났다. 또한 더 어려운 소리를 가진 단어에서 더 변이적이라는 Ferguson과 Farwell (1975)의 결과와도 일치하였다. Kim과 Ha (2016) 역시 아동의 자음 목록에서 늦게 발 달하는 소리, 즉 음소 난이도가 높은 소리에서 변이성이 높게 관찰 되었다고 보고하였다. $\mathrm{Han}$ 과 $\mathrm{Ha}$ (2017)에서 말소리장애 아동과 일 반 아동의 조음 변이성을 조음 복잡도에 따라 살펴본 결과 말소리 장애 유무와 관계없이 조음 복잡도가 높은 어휘에서 높은 변이성 을 보였다. 선행연구 결과들을 종합하여 살펴보았을 때, 음소 난이 도가 정확도와 변이성에 영향을 미치는 요인임을 확인할 수 있었다.

위 내용을 종합하여 본 연구는 변이성이 두드러지는 2 세 후반 아 동을 집중적으로 살펴보고자 하였다. 또한 변이성에 영향을 줄 수 있는 단어 친숙도와 음소 난이도를 고려한 목표단어를 제작하여 말소리장애 아동과 일반 아동의 조음 정확도 및 변이성을 비교하 고자하였다.

\section{연구방법}

\section{연구대상}

본 연구는 만 2 세 6 개월부터 2 세 11 개월까지의 말소리장애 아동 10 명과 일반 아동 14 명, 총 24 명을 대상으로 진행하였다. 말소리장 애 아동은 1) 아동용 발음평가(Assessment of Phonology and Articulation for Children, APAC; Kim, Pae, \& Park, 2007)의 결과가 $16 \%$ ile 미만에 속하며, 2) 수용 및 표현어휘력 검사(Receptive \& Expressive Vocabulary Test, REVT; Kim, Hong, Kim, Jang, \& Lee, 2009)의 수용 및 표현어휘 검사 실시가 가능하며, 3) 부모 및 교사로 부터 감각적, 신경학적, 신체적, 인지적 측면에서 문제가 없다고 보 고받았으며, 4) 조음기관의 구조적 장애가 관찰되지 않은 아동이 다. 일반 아동은 1) 아동용 발음평가(APAC, Kim et al., 2007)의 결 과가 $16 \%$ ile 이상이며, 2) 수용 및 표현어휘력 검사(REVT, Kim et al., 2009)의 수용 및 표현어휘 점수가 -1 SD 이상에 속하고, 3) 부모
Table 1. Participants' characteristics

\begin{tabular}{lllc}
\hline Characteristic & SSD (N=10) & TD (N=14) & $t$ \\
\hline Age (month) & $33.40(1.71)$ & $34.00(1.41)$ & .939 \\
APAC_raw score & $42.40(9.16)$ & $15.57(5.33)$ & $-9.07^{*}$ \\
APAC_PCC (\%) & $39.43(13.08)$ & $77.75(7.61)$ & $9.07^{*}$ \\
REVT_R & $14.00(7.13)$ & $27.43(8.70)$ & 4.01 \\
REVT_E & $10.90(8.01)$ & $32.86(10.30)$ & 5.62 \\
\hline
\end{tabular}

Values are presented as mean (SD).

$\mathrm{SSD}=$ children with speech sound disorders; $\mathrm{TD}=$ typically developing children; APAC_PCC = percentage of consonants correct of Assessment of Phonology and Articulation for Children (Kim et al., 2007); REVT_R=receptive vocabulary raw score of Receptive \& Expressive Vocabulary Test (Kim et al., 2009); REVT_E= expressive vocabulary raw score of Receptive \& Expressive Vocabulary Test (Kim et al., 2009). ${ }^{*} p<.05$.

및 교사로부터 감각적, 신경학적, 신체적, 인지적 측면에서 문제가 없다고 보고받았으며, 4) 조음기관의 구조적 장애가 관찰되지 않은 아동이다.

본 연구에 참여한 아동들의 정보와 공식 검사 결과는 Table 1과 같다. 말소리장애 아동 10 명 중 수용 및 표현어휘력이 정상이었던 아동은 5 명, 약간 지체로 나타난 아동은 5 명이었으나, 독립표본 $t$ 검 정을 실시한 결과 일반아동 집단의 수용 및 표현어휘력(REVT) 원 점수와 유의미한 차이는 나타나지 않았다. 두 집단 간 월령에서도 유의한 차이가 없었으며, 집단 특성 상 아동용 발음평가(APAC)의 원점수 및 자음 정확도에서만 유의미한 차이가 나타났다.

\section{검사 구성 및 검사어·그림 선정}

본 연구에서는 단어 친숙도와음소 난이도가 조음 정확도와 변이 성에 어떠한 영향을 미치는지 확인하기 위해 Macrae (2013)를 참고 하여 20 개의 목표단어를 선정하였다.

단어 친숙도는 $\mathrm{Ha}$ 와 $\mathrm{Pi}$ (2018)연구를 참고하여 친숙한 단어와 비 친숙한 단어로 구분하였다. 본 연구에서는 친숙한 단어는 24-30개 월 아동의 $75 \%$ 이상이 표현하는 단어이며, 비친숙한 단어는 24-30 개월 아동의 $50 \%$ 미만이 사용하는 단어로 정하였다. 단어의 음절 구조는 24-30개월 아동이 빈번하게 사용한다고 제시한 5 개의 구조 (CV, CVC, VCV, CVCV, CVCVC)로 하였다. 친숙한 단어와 비친 숙한 단어 목록을 구성할 때 음절 구조와 조음방법별 음소의 비율 은 모두 동일하게 통제하였다.

음소 난이도는 Kim과 Pae (2005), Lee, Han과 Sim (2004), Macrae (2013)를 참고하여 아동의 음소 습득 연령에 따라서 음소 난이 도 '저'와 '고'에 해당하는 검사어를 선정하였다. 특히 조음 복잡성 지표 점수를 제시한 Lee 등(2004)의 '지표 2. 자음의 조음방법'과도 동일한 분류 방법을 사용하였다. 음소 난이도 '저'에 속하는 단어는 
파열음과 비음으로만 구성되도록 선정하였다. 음소 난이도 '고'에 속하는 단어의 초성은 마찰음, 파찰음, 탄설음으로만 구성되도록 선정하였다. 음소 난이도 '고' ‘저'에 따라서 단어를 선정할 때 음절 구조는 일대일로 매칭하여 동일한 구조로 선정하였다.

검사어에 해당하는 그림은 '언어발달 촉진을 위한 우리말 카드 (Kim, Kim, Pae, \& Jin, 2013)'에서 발췌하였다. 2개의 단어는 우리 말 카드에서 적절한 그림을 찾지 못하여 '글파닉스가 이야기와 만 나다 자음아 모음아 놀자 2 (자음편) (Pae, Seal, Shin, \& Sim, 2018)' 와 '한국 조음음운프로파일(Korean Articulation Phonology Profile, K-APP; Ha, Kim, Seo, \& Pi, in press'에서 각 1개씩의 그림을 추가로 발췌하여 사용하였다.

과제에 포함되는 20 개의 단어가 단어 친숙도와 음소 난이도에 따른 아동의 조음 정확도 및 변이성을 살펴보기 위한 본 연구주제 에 적합한지 검증하고자 타당도 평가를 진행하였다. 설문지를 이용 하여 5 명의 전문가에게 타당도 평가를 실시하였다. 5 명의 전문가는 모두 언어병리학 박사과정생 혹은 박사학위 소지자로 하였다. 전문 가를 대상으로 과제에서 사용하는 단어의 친숙도, 음소 난이도, 검 사어 개수, 그림 타당도를 Likert 3점 척도로 평가하였다. 타당도 평 가는 적절하지 않다(0점), 보통이다(1점), 적절하다(2점)로 응답 받 았으며 2점에 가까울수록 높은 타당도를 의미한다. 그 결과, 단어 친숙도 타당도 1.4 , 음소 난이도 타당도 1.6 , 검사어 개수 타당도 1.6 , 그림 타당도 2 로 나타났다. 전문가들로부터 친숙도 타당도와 관련하여 제안받은 내용을 토대로 8 개의 단어를 변경하였다. 단어 를 다시 선정하는 과정에서 $\mathrm{Ha}$ 와 $\mathrm{Pi}$ (2018)에 포함되지 않은 2개의 단어(이마, 세수)를 선정하였다. 2 개의 단어에 대한 친숙도 타당도 를 동일한 5 명의 전문가들에게 추가적으로 실시한 결과 1.8 로 평가 되어 검사어에 최종 포함시켰다. 본 연구에서 사용된 검사어는 Appendix 1 에 첨부하였다.

\section{자료수집 방법 및 절차}

자료수집은 검사자가 아동의 가정이나 아동이 다니는 어린이집 으로 직접 방문하여 실시하였다. 검사를 실시하기 전에 부모 및 교 사와 면담을 진행하여 아동에 관한 기본적인 정보를 제공받았다. 한국 조음음운프로파일(K-APP)의 PART I 조음기관 구조의 순서 에 따라 아동의 조음기관 구조를 살펴보고 이상이 없음을 확인하 였다. 검사 실시 전 아동에게 목표단어 20 개에 해당하는 그림을 먼 저 보여주고 단어와 그림을 연결하여 익히는 시간을 가졌다. 아동 이 목표단어를 이해하고 수행이 가능함을 확인한 뒤에 본 검사를 실시하였다.

본 검사는 소음이 적은 개별적으로 분리된 방에서 검사자와 아
동이 1:1로 있는 상황에서 진행하였다. 검사 소요시간은 아동 당 40 분에서 1 시간이었다. 검사는 조음 능력을 살펴보기 위한 아동용 발 음평가(APAC), 어휘력을 살펴보기 위한 수용 및 표현어휘력검사 (REVT), 변이성을 살펴보기 위한 목표단어 20개로 구성하였다. 변 이성을 확인하기 위한 목표단어 20개는 각 3회씩 산출하도록 1-3차 에 거쳐 진행되었다. 따라서 아동이 총 산출해야 하는 목표단어의 횟수는 총 60 회이다. 목표단어 1-3차 사이에는 아동용 발음평가 (APAC)와 수용 및 표현어휘력검사(REVT)를 실시하여 1-3차가 연 이어 시행되지 않도록 하였다.

본 검사에서 아동이 그림을 보고 단어를 산출하지 못하는 경우 첫 번째로는 의미적 단서를 제공하고, 두 번째로는 첫 음소 및 음절 단서를 제공하고 그래도 산출하지 못하는 경우에는 검사자가 단어 를 들려주어 아동이 모방할 수 있도록 유도하였다. 아동이 스스로 산출하지 못하고 검사자의 단서 제공에 의한 산출을 했을 경우 2,3 차에서도 동일한 단서를 제공하여 검사어 당 모든 기회에서의 단서 및 모방 여부를 통일하고자하였다.

목표단어 20개는 그림 이름대기 방식으로 진행하였다. 그림은 노 트북(14Z990)을 통하여 $15.5 \times 13 \mathrm{~cm}$ 크기로 제시하였다. 제시 순 서는 E-Prime을 이용하여 무작위로 구성하였다. 아동이 목표단어 를 산출할 경우 검사자가 노트북과 연결된 마우스를 눌러 다음 단 어를 제시하였다. 아동의 모든 반응은 E-Prime과 음성 녹음기 (SONY ICD-PX333)를 통하여 녹음하였다.

\section{자료분석}

자료 수집 후 녹음된 자료를 들으며 음성 전사하여 분석하였다. 조음 정확도는 단어에 포함된 자음과 모음을 모두 고려하는 음소 정확도로 산출하였다. 목표단어 20 개를 3 번 산출하였을 때 아동은 총 204개의 음소를 산출하게 된다. 아동이 정확하게 산출한 음소 의 수를 전체 음소 수인 204로 나눈 뒤 100 을 곱하여 음소 정확도 를 산출하였다.

조음 변이성은 아동이 단어를 3 회 모두 동일하게 산출한 경우 2 점, 3 번 중 2 회는 동일하게 1 회는 다른 형태로 산출한 경우 1 점, 3 번 중 3 회 모두 다른 형태로 산출한 경우 0 점을 부여하여 분석하였다. 아동이 20 개의 모든 목표단어를 3 회씩 동일하게 산출하였다면 아 동이 받을 수 있는 최고점은 40 점이다. 반면 아동이 모든 목표단어 를 3 번의 기회에서 모두 다른 형태로 산출하였다면 아동은 0 점을 받게 된다.

\section{신뢰도}

전체 자료 $20 \%$ 에 해당하는 5 명의 자료를 무작위로 선정하였다. 
아동 반응에 대한 전사 및 분석의 정확성을 판단하기 위하여 검사 자 내 신뢰도를 분석하였다. 조음 정확도 신뢰도는 분석 간의 일치 하는 음소의 수를 전체 음소의 수로 나누어 비율로 살펴보았다. 그 결과 정확도에 대한 검사자 내 신뢰도는 $96.08 \%$ 이었다. 조음 변이 성 신뢰도는 변이성에 부여한 점수를 Cronbach's alpha를 이용하 여 통계적으로 유의한지 살펴보았다. 그 결과 변이성에 대한 검사자 내 신뢰도는 .991이었다.

\section{통계처리}

자료의 통계처리는 SPSS (Statistics Package for the Social Science, Version 25.0IBM)를 이용하였다. 말소리장애 아동과 일반 아 동이 단어 친숙도와 음소 난이도에 따라 조음 정확도 및 변이성에 서 차이를 보이는지 살펴보기 위해 반복측정 이원분산분석(repeated two-way ANOVA)을 실시하였다.

\section{연구결과}

\section{말소리장애 아동과 일반 아동의 단어 친숙도에 따른 조음 정확도}

말소리장애 아동과 일반 아동의 단어 친숙도에 따른 조음 정확 도의 기술 통계 결과는 Table 2 와 같다. 말소리장애 아동과 일반 아 동의 단어 친숙도에 따른 조음 정확도에 차이가 있는지 살펴보기 위하여 반복측정 이원분산분석(repeated two-way ANOVA)을 실 시한 결과는, 말소리장애 아동이 일반 아동보다 유의하게 낮은 정 확도를 보였다 $\left(F_{(1,22)}=24.888, p<.05\right)$. 단어 친숙도에 따라서 조음

Table 2. Descriptive results of accuracy according to word familiarity

\begin{tabular}{llll}
\hline & SSD (N=10) & TD (N=14) & Total ( $N=24)$ \\
\hline Familiarity (\%) & $63.63(12.14)$ & $83.47(6.08)$ & $75.21(13.36)$ \\
Unfamiliarity (\%) & $64.12(11.53)$ & $80.46(6.84)$ & $73.65(12.09)$ \\
Total (\%) & $63.87(11.84)$ & $81.97(6.46)$ & $74.43(12.73)$ \\
\hline
\end{tabular}

Values are presented as mean (SD).

$S S D=$ children with speech sound disorders; $T D=$ typically developing children

Table 3. Descriptive results of variability according to word familiarity

\begin{tabular}{llll}
\hline & $\mathrm{SSD}(\mathrm{N}=10)$ & $\mathrm{TD}(\mathrm{N}=14)$ & Total $(\mathrm{N}=24)$ \\
\hline Familiarity & $12.30(1.95)$ & $17.29(1.20)$ & $15.21(2.93)$ \\
Unfamiliarity & $10.10(2.81)$ & $14.86(1.99)$ & $12.88(3.33)$ \\
Total & $22.40(2.38)$ & $32.15(1.60)$ & $28.09(3.13)$ \\
\hline
\end{tabular}

Values are presented as mean (SD).

SSD = children with speech sound disorders; $T D=$ typically developing children . Possible scores range: 0-40.
정확도는 유의미한 차이가 나타나지 않았다 $\left(F_{(1,22)}=1.728, p=.202\right)$. 말소리장애 유무와 단어 친숙도에 따른 상호작용 효과도 유의미하 지 않았다 $\left(F_{(1,22)}=3.332, p=.082\right)$.

\section{말소리장애 아동과 일반 아동의 단어 친숙도에 따른 조음 변이성}

말소리장애 아동과 일반 아동의 단어 친숙도에 따른 조음 변이 성의 기술 통계 결과는 Table 3 과 같다. 통계분석 결과, 말소리장애 아동이 일반 아동보다 유의하게 높은 변이성을 보이는 것으로 나 타났다 $\left(F_{(1,22)}=52.03, p<.05\right)$. 단어 친숙도에 따른 조음 변이성에서 도 유의미한 차이가 나타났다 $\left(F_{(1,22)}=23.49, p<.05\right)$. 말소리장애 유 무와 단어 친숙도에 따른 상호작용 효과는 유의미하지 않았다 $\left(F_{(1,22)}=.06, p=.813\right)$.

\section{말소리장애 아동과 일반 아동의 음소 난이도에 따른 조음 정확도}

말소리장애 아동과 일반 아동의 음소 난이도에 따른 조음 정확 도의 기술 통계 결과는 Table 4 와 같다. 집단 간 유의한 차이가 나타 나 말소리장애 아동이 일반 아동보다 낮은 조음 정확도를 보였다 $\left(F_{(1,22)}=24.903, p<.05\right)$. 음소 난이도에 따른 음소 정확도에서도 유 의미한 차이를 보였다 $\left(F_{(1,22)}=137.608, p<.05\right)$. 말소리장애 유무와 음소 난이도에 따른 상호작용 효과는 유의미하지 않았다 $\left(F_{(1,22)}=\right.$ $1.710, p=.204)$.

음소 난이도에 따른 차이를 보다 면밀하게 살펴보기 위하여 조 음방법별 정확도를 Table 5에 제시하였다. 비음의 조음 정확도가 $81.15 \%$ 로 가장 높았으며 파열음 $79.55 \%$, 파찰음 $45.60 \%$, 탄설음 $37.04 \%$, 마찰음 $7.87 \%$ 순이었다.

Table 4. Descriptive results of accuracy according to phoneme difficulty

\begin{tabular}{llll}
\hline & SSD $(\mathrm{N}=10)$ & TD $(\mathrm{N}=14)$ & Total $(\mathrm{N}=24)$ \\
\hline Low $(\%)$ & $73.92(15.97)$ & $94.54(3.97)$ & $85.95(14.72)$ \\
High (\%) & $53.82(8.32)$ & $69.40(9.63)$ & $62.91(11.88)$ \\
Total $(\%)$ & $63.87(12.15)$ & $81.97(6.80)$ & $74.43(13.30)$ \\
\hline
\end{tabular}

Values are presented as mean (SD).

$\mathrm{SSD}=$ children with speech sound disorders; $\mathrm{TD}=$ typically developing children .

Table 5. Descriptive results for accuracy of plosive, nasal, affricative, fricative, and flap

\begin{tabular}{ccccccc}
\hline & \multicolumn{2}{c}{ Low } & & \multicolumn{3}{c}{ High } \\
\cline { 2 - 3 } \cline { 5 - 7 } & Plosive & Nasal & & Affricative & Fricative & Flap \\
\hline Accuracy (\%) & 79.55 & 81.15 & & 45.60 & 7.87 & 37.04 \\
\hline
\end{tabular}


Table 6. Descriptive results of variability according to phoneme difficulty

\begin{tabular}{lrrr}
\hline & $S S D(N=10)$ & $T D(N=14)$ & Total $(\mathrm{N}=24)$ \\
\hline Familiarity & $13.40(1.84)$ & $17.29(1.98)$ & $15.67(2.71)$ \\
Unfamiliarity & $9.00(2.58)$ & $14.86(2.35)$ & $12.42(3.80)$ \\
Total & $22.40(2.21)$ & $32.15(2.16)$ & $28.09(3.26)$ \\
\hline
\end{tabular}

Values are presented as mean (SD).

$S S D=$ children with speech sound disorders; $T D=$ typically developing children Possible scores range: 0-40.

\section{말소리장애 아동과 일반 아동의 음소 난이도에 따른 조음 변이성}

말소리장애 아동과 일반 아동의 음소 난이도에 따른 조음 변이 성의 기술 통계 결과는 Table 6과 같다. 통계분석 결과 말소리장애 아동이 일반 아동보다 유의하게 높은 변이성을 보였다 $\left(F_{(1,22)}=52.03\right.$, $p<.05)$. 음소 난이도에 따른 조음 변이성에서도 유의미한 차이가 나타났다 $\left(F_{(1,22)}=31.195, p<.05\right)$. 말소리장애 유무와 음소 난이도 에 따른 상호작용 효과는 유의미하지 않았다 $\left(F_{(1,22)}=2.60, p=.121\right)$.

음소 난이도에 따른 차이를 보다 면밀하게 살펴보기 위하여 조 음방법별 변이율을 Table 7에 제시하였다. 조음방법별로 산출 기회 의 수가 서로 다르기 때문에 조음방법별로 변이성을 보인 자음 유 형을 해당 자음 유형의 산출 기회의 총수로 나누어 조음방법별 변 이율을 구하였다. 마찰음의 변이율은 $49.31 \%$ 로 가장 높은 변이성 을 보이는 것으로 나타났으며, 파찰음 $42.36 \%$, 탄설음 $30.56 \%$, 파 열음 $26.14 \%$, 비음 $17.86 \%$ 순이었다.

\section{논의 및 결론}

본 연구는 2세 후반 말소리장애 아동과 일반 아동을 대상으로 단어 친숙도와 음소 난이도에 따른 조음 정확도 및 변이성을 살펴 보았다. 단어 친숙도에 따른 집단 간 조음 정확도와 변이성을 살펴 본 결과, 단어의 친숙도는 조음 정확도에 유의한 영향을 끼치지 않 았으나 조음 변이성에는 유의한 영향을 끼치는 것으로 나타났다. 단어 친숙도에 따른 정확도의 유의미한 차이가 없었던 본 연구의 결과는 단어 친숙도에 따라 아동의 조음 정확도가 달라지지 않는 다고 보고한 Macrae (2013)의 연구와는 일치하였으나, Sosa와 Stoel-Gammon (2012)의 결과와는 일치하지 않았다. Sosa와 StoelGammon은 비친숙한 단어가 친숙한 단어보다 높은 정확도를 보 인다고 보고하였다. 그들은 이러한 현상을 아동이 단어를 받아들 이는 시점과 음운체계 발달 정도를 연관 지어 설명하였다. 아동들 은 비친숙한 단어를 친숙한 단어보다 늦게 받아들이게 된다. 비친 숙한 단어를 습득하는 시점에는 친숙한 단어를 받아들였던 때보
Table 7. Descriptive results for variability of plosive, nasal, affricative, fricative, and flap

\begin{tabular}{lcccccc}
\hline & \multicolumn{2}{c}{ Low } & & \multicolumn{3}{c}{ High } \\
\cline { 2 - 3 } \cline { 5 - 7 } \cline { 5 - 7 } & Plosive & Nasal & & Affricative & Fricative & Flap \\
\hline Variability (\%) & 26.14 & 17.86 & & 42.36 & 49.31 & 30.56 \\
\hline
\end{tabular}

다 발달된 음운체계를 갖추고 있기 때문에 보다 정확한 형태로 표 현하는 것이 가능하다. 반면 이전에 산출하기 시작한 친숙한 단어 는 이후에 이루어진 음운체계상의 변화와 발달에 아직 적용되지 않아 여전히 부정확하게 산출될 수 있다. 따라서 친숙한 단어보다 비친숙한 단어에서 더 높은 정확도를 보이게 된다고 해석하였다.

단어 친숙도에 따른 변이성에서 유의미한 차이가 있었던 본 연구 의 결과는 단어 친숙도에 따라 변이성이 달라지지 않는다고 보고한 Sosa와 Stoel-Gammon (2012) 그리고 Macrae (2013)의 연구 결과 와 일치하지 않았다. 이는 연구마다 단어 선정 방법이 달랐기 때문 으로 해석할 수 있다. 먼저 Sosa와 Stoel-Gammon은 양육자를 대 상으로 어휘 체크리스트를 실시하여 아동이 실제로 사용하는 단 어를 파악한 뒤에 목표단어를 선정하였다. 최대한 아동들이 공통 적으로 사용하는 단어를 선정하였으나 단어에 포함되는 자음을 세밀하게 통제하지는 못하였다. Macrae (2013)는 18개월 아동의 $50 \%$ 이상이 사용하는 단어를 친숙한 단어, $50 \%$ 미만이 사용하는 단어를 비친숙한 단어로 설정하였다. 그러나 선행연구의 대상자가 21-37개월로 구성되었기 때문에 목표단어 선정 시 기준으로 삼은 18 개월은 가장 어렸던 21 개월 아동보다도 이른 시기였다. 따라서 비 친숙한 단어로 설정된 단어가 실제로는 연구 대상자들에게는 친숙 한 단어로 작용했을 수 있다.

단어 친숙도에 따라서 비교해 보았을 때, 본 연구에서는 말소리 장애 아동은 일반 아동보다 조음 정확도가 유의하게 낮을 뿐만 아 니라 조음 변이성도 유의하게 높은 것으로 나타났다. 이는 말소리 장애 아동의 경우 일반 아동에 비하여 말 산출이 부정확하면서 오 류의 형태가 다양하여 불안정한 산출을 보이는 것으로 해석할 수 있다. 또한, 변이성이 일반적으로 높다고 여겨지는 만 2 세의 연령에 서 말소리장애 아동은 일반 아동보다 유의하게 높은 변이성을 보 여, 말 습득 과정에서 보이는 정상적인 조음 변이성보다 높은 특성 을 보이는 것으로 나타났다.

음소 난이도에 따른 집단 간 조음 정확도와 변이성을 살펴본 결 과, 음소 난이도는 조음 정확도와 조음 변이성에 유의한 영향을 끼 치는 것으로 나타났다. 조음 정확도는 음소 난이도 '저'보다 '고'에 서 유의하게 낮게 나타났으며, 조음 변이성은 음소 난이도 '저'보다 '고'에서 유의하게 높게 나타났다. 조음방법별로 조음 정확도와 변 
이성을 자세히 살펴보면, 파열음과 비음은 정확도는 높고 변이성이 낮았으며, 마찰음, 탄설음, 파찰음의 정확도는 낮고 변이성이 높은 경향성을 보였다. 이는 더 어렵고 복잡한 소리에서 높은 변이성을 보였다는 국내외 선행연구와 유사한 결과였다(Ferguson \& Farwell, 1975; Han \& Ha, 2017; Kim \& Ha, 2016; Macrae, 2013; Sosa \& Stoel-Gammon, 2012). 음소 난이도 '고'에서 낮은 정확도와 높은 변이성을 보였던 이유로 본 연구의 검사어에 포함된 음소의 습득 연령을 생각해 볼 수 있다. 음소 난이도 '고'에 포함된 소리는 대상 자의 연령인 2 세 후반에 아직 발달하지 않은 마찰음, 유음 그리고 파찰음이었다. 파찰음의 경우 $\mathrm{Kim}$ 과 $\mathrm{Pae}$ (2005)에 따르면 초성 /ㅊ, 찌는 2세 후반에 $50 \%$ 이상의 아동들이 정확하게 산출하며 3 세 전반이 되면 $75 \%$ 이상의 아동이 정확하게 산출한다. 초성 /ㅈ/ 는 3 세 전반에 $50 \%$ 이상의 아동들이 산출하기 시작하여 3 세 후반 이 되면 $75 \%$ 이상의 아동이 정확하게 산출하게 되어 숙달 연령에 이르게 된다. 일음절 낱말을 토대로 자음의 습득 연령을 살펴본 $\mathrm{Ha}, \mathrm{Kim}$ 과 $\mathrm{Pi}$ (2019)는 초성 / 지의 경우 2 세 후반에 $75 \%$ 이상의 아 동이 정확하게 산출하지만 초성 /ㅊ, 찌는 4 세 전반이 되어야 $75 \%$ 이상의 아동이 정확하게 산출한다고 하였다. 본 연구에서 2 세 후반 아동의 파찰음 정확도는 $45.60 \%$ 로 나타나 앞서 언급한 선행연구 와 비교해서 낮게 나타났다. 이러한 정확도의 차이는 검사어를 구 성하는 음절 수와 구조, 음운환경, 친숙도 등으로 설명된다. 예를 들어 $\mathrm{Ha}$ 등(2019)은 초성 [지의 정확도를 CVC 일음절 구조의 [이] 모음 환경 앞에서 살펴보았기 때문에 상대적으로 습득 시기가 빠 르게 나타났다. 그러나 이러한 차이에도 불구하고 세 연구의 결과 를 통하여 2 세에서의 파찰음은 습득해 나가는 중간 과정 중에 있 음을 확인할 수 있다. 마찰음 정확도는 $7.87 \%$, 유음 정확도는 $37.04 \%$ 로 파찰음보다 낮았으며 마찰음과 유음의 경우 아직 2세 아 동의 음운체계에 안정적으로 포함되지 않은 음소로 나타났다. 즉, 음소 난이도는 아동으로 하여금 낮은 정확도와 높은 변이성을 보 이게 만드는 요소임을 확인 수 있다.

변이성 점수 총점 40 점 중 일반아동은 32.15점, 말소리장애 아동 은 22.40 점으로 일반 아동은 검사어의 $32.5 \%$, 말소리장애 아동은 $63.5 \%$ 를 서로 다른 형태로 산출하였다. 자음과 모음을 모두 고려 한 음소 정확도로 말소리장애 아동과 일반 아동의 조음 정확도를 비교하였기 때문에 아동의 모음 오류도 반영이 되었다. 특히 말소 리장애 아동의 경우에는 아동기말실행증(CAS)의 특징이기도 한 모음 오류가 빈번하게 관찰되었다. 말소리장애 아동과 일반 아동이 3 회씩 산출한 단어들을 토대로 변이성을 자세히 살펴보면, 일반 아 동은 '세수'를 /테두-테두-테두/와 같이 산출하여 동일한 목표 음소 로의 대치를 보였다. 그러나 말소리장애 아동은 /테두-헤투-체뚜/
와 같이 동일한 목표 음소를 다양한 소리로 대치하고 일부 아동은 비발달적인 오류패턴도 함께 보였다. 즉, 일반 아동은 동일하고 일 관적인 형태의 오류패턴이 나타났으나 말소리장애 아동은 모음 오 류와 비발달적인 오류패턴도 보이면서 비일관적인 산출을 보였다. 말소리장애 아동과 일반 아동의 반응을 4 가지로 나누어 분석한 $\mathrm{Ha}$ (2020)에서도 일반 아동과 달리 말소리장애 아동은 일관적이 고 정확한 반응이 유의하게 낮았으며 변이적인 산출이 유의하게 높 았다. 특히 비일관적 음운장애는 비일관적이고 부정확한 반응이 다른 하위유형의 말소리장애보다 높게 나타나 다른 하위유형과 구 별되었다. 말소리장애 아동의 비일관적인 산출 형태는 말 처리 과정 의 광범위한 어려움 혹은 하나의 근본적인 결함으로 인한 여러 단 계의 어려움으로 나타나기 때문에 오류에서의 규칙을 찾기 어렵다. 따라서 특징을 고려한 효과적인 치료목표를 설정하여 중재를 진행 해야 한다(Ha \& Seo, 2019).

3세 미만의 어린 연령대의 말소리장애 아동의 경우 음운 발달상 의 제한으로 인해 어휘 발달상의 어려움을 함께 보일 수 있다 (Locke, 1983; Stoel-Gammon, 2011). 따라서 조기 평가를 통한 선 별과 개입이 중요시된다. 본 연구에 따르면 음소 습득 초기 단계에 해당하여 발달적으로 변이성을 두드러지게 보이는 2 세 후반에서 도 말소리장애 아동과 일반 아동의 변이성이 단어 친숙도와 음소 난이도에 따라 유의미하게 다르게 나타나고 서로 구분되는 특징을 보였다. 이러한 연구 결과는 2 세 후반의 말소리장애 아동을 진단하 고, 음운 습득을 촉진하고 음운 발달 상의 제한으로 인해 어휘 표 현상의 어려움을 예방할 수 있는 조기 개입을 제공할 수 있는 근거 로 활용할 수 있겠다.

종합하여 살펴보면 말소리장애 아동은 일반 아동보다 낮은 조음 정확도와 높은 변이성을 보였다. 특히 발달적으로 조음 변이성을 크게 보이는 2세 후반에서도 일반 아동과 말소리장애 아동의 특징 이 상이하게 나타났다. 이러한 연구결과는 조음 변이성을 기준으 로 3세 미만의 어린 아동을 대상으로 말소리장애 진단을 할 수 있 음을 제안하고 있다. 더 나아가 말소리장애 진단을 위해 검사어를 선택할 때에는 친숙도와 음소 난이도를 고려해야 하며, 이는 말소 리장애아동을 중재함에 있어서도 고려해야 할 것이다.

\section{REFERENCES}

Burt, L., Holm, A., \& Dodd, B. (1999). Phonological awareness skills of 4year-old British children: An assessment and developmental data. International Journal of Language \& Communication Disorders, 34(3), 311-335.

Dodd, B. (2005). Differential diagnosis and treatment of children with speech 
disorder. London: Whurr.

Ferguson, C. A., \& Farwell, C. B. (1975). Words and sounds in early language acquisition. Language, 51(2), 419-439.

Ha, S. (2020). Variability and inconsistency in children with and without speech sound disorders. Communication Sciences \& Disorders, 25(2), 431440.

Ha, S., Kim, M., Seo, D., \& Pi, M. (in press). Korean Articulation Phonology Profile (K-APP). Seoul: Human Brain Research and Consulting.

Ha, S., Kim, M., \& Pi, M. (2019). Percentage of consonants correct and age of acquisition of consonants in Korean-speaking children in one-syllable word contexts. Communication Sciences \& Disorders, 24(2), 460-468.

Ha, S., \& Pi, M. (2018). Phonological characteristics of early lexicon in Korean-acquiring children. Communication Sciences \& Disorders, 23(4), 829844.

Ha, S., \& Seo, D. G. (2019). Articulatory consistency for differential diagnosis of speech sound disorders. Communication Sciences \& Disorders, 24(4), 1015-1025.

Han, E. J., \& Ha, J. W. (2017). Variability of speech sound production accord। -ing to phonetic complexity in children with and without speech sound disorders. Communication Sciences \& Disorders, 22(4), 772-783.

Holm, A., Crosbie, S., \& Dodd, B. (2007). Differentiating normal variability from inconsistency in children's speech: normative data. International Journal of Language and Communication Disorders, 42(4), 467-486.

Hwang, J., \& Ha, S. (2012). A study of articulatory variation in typically delveloping children between 2 and 4 years of age. Korean Journal of Communication \& Disorders, 17(3), 403-413.

Kim, H. J., Kim, M. B., Pae, S., \& Jin, Y. S. (2013). Korean words card for for promoting language development. Seoul: Hakjisa.

Kim, H. Y., \& Ha, S. (2016). Articulatory variability in 24-to 36-month-old typically developing children. Communication Sciences \& Disorders, 21(2), 333-342.

Kim, M., Pae, S., \& Park, C. (2007). Assessment of Phonology \& Articulation for Children (APAC). Incheon: Human Brain Research \& Consulting.

Kim, M., \& Pae, S. (2005). The percentage of consonants correct and the ages of consonantal acquisition. Korean-Test of Articulation for Children (KTAC). Korean Society of Speech Sciences, 12(2), 139-149.

Kim, S. J., \& Shin, J. Y. (2015). Speech sound disorders. Seoul: Sigma Press.

Kim, Y., Hong, K., Kim, K., Chang, H., \& Lee, J. (2009). Receptive and Expressive Vocabulary Test (REVT). Seoul: Seoul Community Rehabilitation Center.

Lee, E., Han, J., \& Sim, H. (2004). The effects of the phonetic complexity on the disfluencies and the articulation errors of people who stutter. Korean Journal of Communication \& Disorders, 9(3), 139-156.

Locke, J. L. (1983). Phonological acquisition and change. New York, NY: Academic Press.

Macrae, T. (2013) Lexical and child-related factors in word variability and accuracy in infants. Clinical Linguistics \& Phonetics, 27(6-7), 497-507.

McLeod, S., \& Hewett, S. R. (2008). Variability in the production of words containing consonant clusters by typical 2- and 3-year-old children. Folia Phoniatrica et Logopaedica, 60(4), 163-172.

Pae, S., \& Kwak, K. (2011). Korean version of MacArthur-Bates Communicative Development Inventory (K M-B CDI). Seoul: Mindpress.

Pae, S., Seal, A. , Shin, G., \& Sim, Y. (2018). Korean phonics meets story (Vol.2) : Let's play with vowels and consonants. Durubarun.

Schwartz, R. G., Leonard, L. B., Folger, M. K., \& Wilcox, M. J. (1980). Early phonological behavior in normal-speaking and language disordered children: evidence for a synergistic view of linguistic disorders. Journal of Speech and Hearing Disorders, 45(3), 357-377.

Sosa, A. V., \& Stoel-Gammon, C. (2006). Patterns of intra-word phonological variability during the second year of life. Journal of Child Language, 33(1), 31-50.

Sosa, A. V., \& Stoel-Gammon C. (2012). Lexical and phonological effects in early word production. Journal of Speech, Language, and Hearing Research, 55(2), 596-608.

Stoel-Gammon, C. (2011). Relationships between lexical and phonological development in young children. Journal of Child Language, 38(1), 1-34.

Thelen, E., \& Bates, E. (2003). Connectionism and dynamic systems: are they really different?. Developmental Science, 6(4), 378-391. 
Appendix 1. 단어 친숙도와 음소 난이도에 따른 검사어

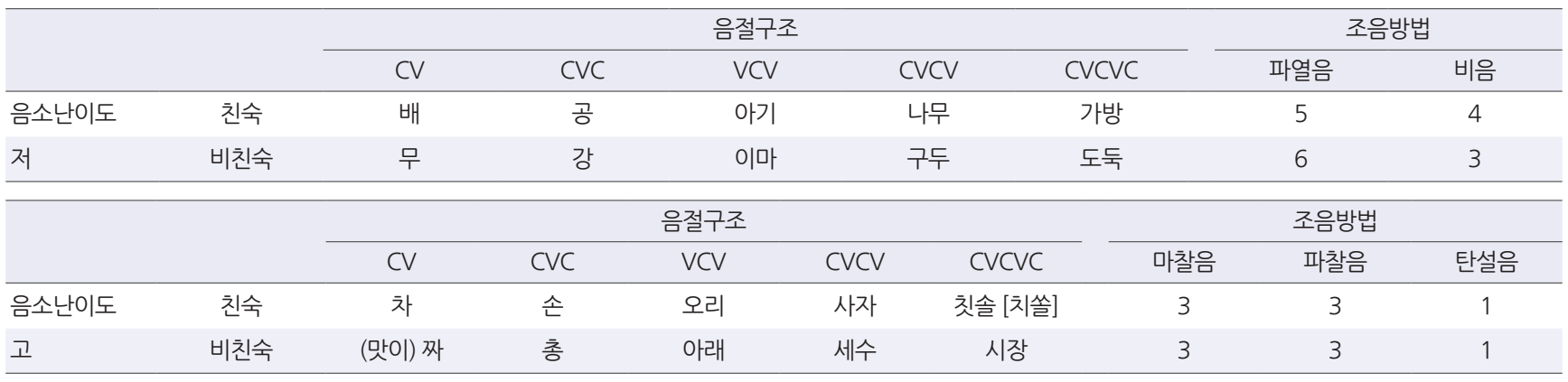




\section{국문초록}

\section{단어 친숙도와 음소 난이도에 따른 말소리장애 아동과 일반 아동의 조음 정확도 및 변이성 장지수 ${ }^{*}$ 하승희 ${ }^{2}$}

'한림대학교 대학원 언어병리청각학과, ${ }^{2}$ 한림대학교 언어청각학부, 한림청각언어연구소

배경 및 목적: 본 연구는 단어 친숙도와 음소 난이도에 따른 말소리장애 아동과 일반 아동의 조음 정확도 및 변이성을 살펴보고자 하 였다. 방법: 만 2 세 6 개월-11개월 말소리장애 아동 10 명과 일반 아동 14 명이 본 연구에 참여하였다. 단어 친숙도와 음소 난이도를 고려 하여 목표단어 20 개를 제작하였다. 20 개의 단어를 각 3 번씩 산출하도록 하였으며 음소 정확도와 변이성 점수를 구하였다. 결과: 말소리 장애 아동은 일반 아동보다 유의미하게 낮은 정확도와 높은 변이성을 보였다. 단어 친숙도에 따라 살펴보았을 때 정확도는 유의미한 차 이가 없었으나 변이성은 유의미한 차이가 나타났다. 음소 난이도에 따라서는 정확도와 변이성 모두에서 유의미한 차이를 보였다. 논의 및 결론: 본 연구는 2세 6-11개월 말소리장애 아동과 일반 아동에게 단어 친숙도와 음소 난이도는 조음 정확도에 영향을 끼치고 음소 난이도에 따라 조음 변이성도 달라짐을 보여주고 있다. 조음 변이성과 관련 요인을 정상적이거나 지연 또는 병리적인 말소리 습득 과정 의 관점에서 논의하였다. 본 연구는 3 세 미만의 말소리장애 아동의 진단과 중재에 대해 시사하는 바가 있다.

핵심어: 말소리장애, 단어 친숙도, 음소 난이도, 정확도, 변이성

\section{참고문헌}

김민정, 배소영, 박창일 (2007). 아동용 발음평가(APAC). 인천: 휴브알앤씨.

김민정, 배소영 (2005) ‘ '아동용 조음검사’를 이용한 연령별 자음정확도와 우리말 자음의 습득연령·음성과학, 12(2), 139-149.

김수진, 신지영 (2015). 말소리장애. 시그마프레스.

김영태, 홍경훈, 김경희, 장혜성, 이주연 (2009). 수용 표현어휘력검사(REVT). 서울: 서울장애인종합복지관.

김효진, 김미배, 배소영, 진연선 (2013). 언어/읽기 발달 촉진을 위한 우리말 카드. 서울: 학지사.

김희윤, 하승희 (2016). 24-36개월 아동의 조음 변이성 연구. Communication Sciences \& Disorders, 21(2), 333-342.

배소영, 곽금주 (2011). 한국판 맥아더-베이츠 의사소통발달평가(K M-B CDI). 서울: 마인드프레스.

배소영, 설아영, 신가영, 심유미 (2018). 한글파닉스가 이야기와 만나다자음아 모음아 놀자 2 (자음편). 두루바른.

이은주, 한진순, 심현섭 (2004). 조음복잡성이 비유창성과 조음오류에 미치는 영향. 언어청각장애연구, 9(3), 139-156.

하승희 (2020). 말소리장애와 일반 아동의 정상적인 변이성과 병리적 비일관성. Communication Sciences \& Disorders, 25(2), 431-440.

하승희, 김민정, 서동기, 피민경 (출판중). 한국 조음음운프로파일(K-APP). 서울: 휴브알앤씨.

하승희, 김민정, 피민경 (2019). 일음절 낱말 과제에서 살펴본 한국 아동의 자음정확도와 습득 연령. Communication Sciences \& Disorders, 24(2),

460-468.

하승희, 서동기 (2019). 말소리장애 감별 진단을 위한 조음 일관성 연구. Communication Sciences \& Disorders, 24(4), 1015-1025.

하승희, 피민경 (2018). 12-30개월 아동의 초기 어휘에 나타난음운 특성. Communication Sciences \& Disorders, 23(4), 829-844.

한은지, 하지완 (2017). 말소리장애 아동과 일반 아동의 조음복잡성에 따른 조음변이성 연구. Communication Sciences \& Disorders, 22(4), 772-783.

황진경, 하승희 (2012). 2 세 후반-4 세 아동의 조음 변이성 연구. 언어청각장애연구, 17(3), 403-413.

\section{ORCID}

장지수(제1저자, 대학원생 https://orcid.org/0000-0003-1345-5883); 하승희(교신저자, 교수 https://orcid.org/0000-0003-2133-3720) 